\title{
Accessibility Index of Aquatic Environments as an Indicator of Surface Water Vulnerability in Urban Areas: Case of the Okpara Basin (Benin)
}

\author{
Maurille P. S. Lanmandjèkpogni ${ }^{1,2,3^{*}}$ (D), François De Paule Codo ${ }^{1}$, Babilas Hountondji1, \\ Benjamin Kouassi Yao ${ }^{3}$
}

\footnotetext{
${ }^{1}$ Laboratory of Water Science and Technology (LSTE), National Water Institute (INE), University of Abomey-Calavi, Cotonou, Benin ${ }^{2}$ International Chairin Mathematical Physics and Applications (CIPMA), University of Abomey-Calavi, Cotonou, Bénin ${ }^{3}$ Laboratory of Industrial Processes, Briefs, Environment and New Energy (LAPISEEN), Process Group and Environment, National Polytechnic Institute Houphouet-Boigny (INP-HB), Yamoussoukro, Ivory Coast

Email: *paolorossi_bj@yahoo.fr
}

How to cite this paper: Lanmandjèkpogni, M.P.S., De Paule Codo, F., Hountondji, B. and Yao, B.K. (2019) Accessibility Index of Aquatic Environments as an Indicator of Surface Water Vulnerability in Urban Areas: Case of the Okpara Basin (Benin). Open Journal of Modern Hydrology, 9, 103-112. https://doi.org/10.4236/ojmh.2019.94006

Received: June 24, 2019

Accepted: September 9, 2019

Published: September 12, 2019

Copyright $\odot 2019$ by author(s) and Scientific Research Publishing Inc. This work is licensed under the Creative Commons Attribution International License (CC BY 4.0).

http://creativecommons.org/licenses/by/4.0/

\begin{abstract}
Physiographic differences and conditions of use of water resources in anthropogenic basins explain the variability of risk to surface water. Based on the multi-criteria analysis of Saaty, the present work proposes an assessment of the vulnerability of surface water through a three-factor accessibility index: the slope, the subdivision rate and the drainage density of the basin. It is observed that the topographic (slope) and urbanistic (subdivision) conditions are the most important (weighting of 59\%, 34\%) in front of the hydrographic condition (drainage 6\%) with an overall consistency of $2 \%$. Thus, in the Okpara basin in the city of Parakou, the analysis of the vulnerability of surface waters by the accessibility index highlights two groups. The Ganré and Kokouro basins with about $30 \%$ of their areas in the low and moderate classes and the Wonka and Dama basins in the very strong class at more than $50 \%$ of their areas.
\end{abstract}

\section{Keywords}

Accessibility, Risk, Vulnerability, Index, Okpara

\section{Introduction}

Access to drinking water which is a global objective of sustainable development is increasingly threatened by the pressure of uses on all resources, particularly terrestrial aquatic ecosystems [1]. This threat is a notable weakness in the social and political stability of populations regarding the management of water re- 
sources; especially for developing countries, considering the accelerating pace of demographic, urban and socio-economic growth recorded at the beginning of the 21st century [2]. According to [3], the renewal of surface water is influenced by rain runoff and controlled by ecohydrological specificities and as a result, uneven distribution on land. When referring to global statistics [1], the seriousness of the issue of access to water resources is better understood both globally and regionally [4]. In the context of rapid population growth coupled with the difficulties of access to land in developing countries, the peri-urbanization of ancient nuclei is very spontaneous and generally occurs in the absence of spatial planning [5] [6]. Years ago, several studies have attempted to evaluate the influence of uses, especially anthropogenic uses on the quality of water in the resource [7]-[12]. Within this framework, many methods have been used to assess groundwater vulnerability [13] [14] [15] [16] [17], but very few are interested in surface water [15] [18]. This apparent lack of interest is due, among other things, to the complexity of the surface water pollution mechanisms, on the one hand, and the active involvement of the geomorphometric specificities of the basins on the other and in addition to the rather well-known role of anthropic activities. The hydrographic system of the city of Parakou (West Africa) is divided into the basins of Upper Ouémé and that of Okpara. According to the administrative division of the city and the demographic statistics [19], nearly $70 \%$ of the urban slice of the city is found in the Okpara basin. The geographical boundaries of the city have moved quite rapidly over the last two decades with a gradual and monocentric occupation to the north-east and south-west of the Okpara Basin. It follows from these observations that the aquatic systems of this basin would be exposed to a greater risk of pollution due to the phenomenon of urban sprawl. The aim of the study is to evaluate, using Geographical Information Systems (GIS) tools and multicriteria analysis, an index of accessibility of hydrographic networks as an indicator of vulnerability of surface waters in the Okpara basin at Parakou.

\section{Study Area}

The work is done on the Okpara basin in the city of Parakou. The Okpara basin is about $235 \mathrm{~km}^{2}$ in total, but consists of four sub-basins of small size in the town of Parakou located between the latitudes North $9^{\circ} 15^{\prime}$ and $9^{\circ} 27^{\prime}$, then longitudes East $2^{\circ} 31^{\prime}$ and $2^{\circ} 45^{\prime}$. It presents a four-level fishbone hydrographic network according to Strahler's classification. The city is densely populated, strong in areas of ancient settlement (the urban core) and decreasing in size to peripheral areas. The terrain is sloping North-South and North-East. The thalwegs of the four sub-basins (Ganré, Wonka, Kokouro and Dama) are positioned as the main transport channels of all urban pollution towards the Okpara River (Figure 1).

\section{Matérials and Methods}

\subsection{Definition of Accessibility Factors}

According to [20], the mapping approach to the intrinsic vulnerability of surface 




Figure 1. Study location. Source: Fond Topograhique IGN, 1992 plus données de terrain 2016.

water catchments takes into account a factor related to the accessibility of the aquatic environment. The authors evaluated this factor with the only parameter of the geometric distance between the pollutant emission point and the aquatic environment. Several studies have established that surface water pollution is strongly linked to anthropogenic activities [21] [22] [23] [24] [25]. However, the transport of pollutants emitted to water plan depends on several other geomorphological parameters of watersheds. The probability of pollution entering the water system is a function of basin occupancy conditions, geomorphological features and the existence of the drainage network. The construction of an impact chain has allowed us to identify three parameters controlling the accessibility of aquatic systems (Figure 2).

\subsection{Data of the Study}

We extracted the Digital Terrain Model (DTM) from the study area from the 30 $\mathrm{m} \times 30 \mathrm{~m}$ (Shuttle Radar Topography Mission: SRTM 30, geoid WGS 84) square mesh raster, downloadable from the site (http://lta.cr.usgs.gov/srtm), then delimited the Okpara basin into four sub-basins designated by the names of their main talwegs: the sub-basins of Ganré, Wonka, Kokouro and the Dama sub-basin. This Digital Model was used to then generate the slope map and the drainage density map for each of the basins. The variation of these mapped indices has been neglected since the study area is geologically stable. The urban settlement map is obtained with the fragmentation polygons represented by their centroids throughout the basin. The situation for each basin was obtained by geoprocessing of the contours of the city with those of a centroids density map on the basins from updated files in dwg. format, subdivisions of 2004 and 2014 financed by the Millennium Challenge Account in Benin. Each of the mapped indices has been reclassified into five accessibility classes (Table 1). 




Figure 2. Chain of impact and factors of accessibility according to the method of Adelphi/Eurac, 2014.

Table 1. Classes of vulnerability according to BRGM.

\begin{tabular}{cccccc}
\hline Classe & 1 & 2 & 3 & 4 & 5 \\
\hline \multirow{2}{*}{ Description } & Very weak & Weak & Moderate & Strong & Very strong \\
\hline
\end{tabular}

\subsection{Weighting Factors}

Identified as the first condition of vulnerability of water resources in general, accessibility is for surface water one of the factors of expression of both the existence of pollution (activity of the source of pollution), and topographical conditions favorable to the contact between the aquatic environment and the polluting emission. However, in the light of BRGM's work, accessibility seems to be limited to the notion of proximity. It is then evaluated and mapped by the distance (in meters) separating the aquatic environment and the emission point from the pollution. In this work, we rather retain the principle of integrated effects of several factors on accessibility as an indicator of the vulnerability of surface water; thus this parameter is developped under a weighted combination of three factors. For time tracking purposes, the maps were produced for the dates 2004 and 2014. The multicriteria analysis method was used to weight the parameters identified in the chain of impacts (Figure 2). The expression of calculation of the index of accessibility of the hydrographic network on a basin is characterized by the form.

$$
D=a_{P} \cdot P+b_{I} \cdot I_{l o t}+c_{d r} \cdot d_{d r} \text { and } 1=a_{p}+b_{I}+c_{d r} \quad\left(\begin{array}{lll}
a_{p} & b_{I} & c_{d r}
\end{array}\right) \in \mathfrak{R}^{3}
$$

This technique developped by Saaty towards the end of the 70's, allows to evaluate by a controlled decision process, the weights of each of the parameters from their comparison in pairs with criteria chosen to reach the goal. It has been used successfully for several works [26] [27]. Firstly, a comparison of the criteria was made by a square matrix of order 3 . The scores are assigned according to Saaty's scorecard (Table 2) and respect the relation: 


$$
a_{i j} \cdot a_{j i}=1
$$

$a_{i j}$ : Note translating the importance of the factor $i$ compared to the factor $j$.

$a_{j i}$ : Note translating the importance of the factor $j$ compared to the factor $i$.

$a_{i j} \succ 1: i$ has more high importance compared to factor $j$ in the decision.

$a_{i j} \prec 1: i$ has more weak importance compared to factor $j$ in the decision.

We thus constituted a square matrix of order 3, also called original matrix. The original matrix is used in the computation of the eigenvectors with the expression:

$$
A_{\text {orig }}=\left(\begin{array}{lll}
a_{11} & a_{12} & a_{13} \\
a_{21} & a_{22} & a_{23} \\
a_{31} & a_{32} & a_{33}
\end{array}\right) \text { and } V_{P i}=\sqrt[n]{a_{i 1} \cdot a_{i 2} \cdot a_{i 3}}, \quad i=1,2,3
$$

$a_{i j}$ : Assigned value at $i^{\text {th }}$ parameter in $f^{\text {th }}$ columnar of matrix columnar $A_{\text {orig }}$ $n$ : Number of parameters analysed $(n=3)$.

$V_{P i}$ : Own vector of parameter $i$.

Each parameter $i$ is thus weighted by coefficient $C_{P i}$ :

$$
C_{P i}=\frac{V_{P i}}{\sum_{i=1}^{n} V_{P i}} \text { with } \sum_{i=1}^{n} C_{P i}=1
$$

The calculated weights are validated from the coherence or consistency ratio of the original matrix. Validation of the weights consists in eliminating or failing, minimizing possible errors of judgments made on the parameters during the notation. These errors are translated into the consistency ratio and depend on the number of parameters of the study. The coherence ratio is a function of a random index, the rational priority of the parameters and the number of parameters $n$. The priority vectors are obtained from the standardized matrix of as follows (Table 3):

Table 2. Grid for scoring parameters [28].

Importance on
$\begin{aligned} & 1 \\ & 2\end{aligned}$
$\begin{aligned} & \text { Both elements have the same importance } \\ & \text { The line element is slightly larger. } \\ & \text { The line element is a bit more important } \\ & 5\end{aligned}$
The line element is moderately more important.
The line element is significantly more important than the columnar one.
8

Table 3. Repository of random indices [28].

\begin{tabular}{cccccccccc}
\hline Number of parameters & 2 & 3 & 4 & 5 & 6 & 7 & 8 & 9 & 10 \\
\hline IA: Random index & 0 & 0.58 & 0.9 & 1.12 & 1.24 & 1.32 & 1.41 & 1.45 & 1.49 \\
\hline
\end{tabular}




$$
A_{\text {orig }}=\left(\begin{array}{lll}
b_{11} & b_{12} & b_{13} \\
b_{21} & b_{22} & b_{23} \\
b_{31} & b_{32} & b_{33}
\end{array}\right) \text { with } b_{i j}=\frac{a_{i j}}{\sum_{j=1}^{n} a_{j k}} \text { and } \sum_{j=1}^{n} b_{j k}=1, k=1,2,3
$$

The consistency ratio is calculated with the expression

$$
R C=\frac{\lambda_{\max }-n}{n-1} \cdot \frac{1}{I A} \text { with } \lambda_{\max }=\frac{1}{n} \sum_{i=1}^{n}\left(\frac{\sum_{j=1}^{n} a_{i j} \cdot w_{j}}{w_{i}}\right)
$$

\section{Results and Discussion}

The matrixes $A_{1}$ and $A_{2}$ are those used for the original and standardized matrices respectively in the calculation process (Table 4 ):

$$
A_{1}=\left(\begin{array}{lll}
1.00 & 2.00 & 8.00 \\
0.50 & 1.00 & 6.00 \\
0.13 & 0.17 & 1.00
\end{array}\right) \text { and } A_{2}=\left(\begin{array}{ccc}
0.62 & 0.63 & 0.53 \\
0.31 & 0.32 & 0.40 \\
0.08 & 0.05 & 0.07
\end{array}\right)
$$

A weighting of $59 \%, 34 \%$ and $6 \%$ respectively for the slope index, the gross subdivision index and finally the urban drainage is obtained for the calculation of accessibility on the basins. The graphs shown in Figures 3(a)-(d) above are derived respectively from the aquatic accessibility maps, developped from a multi-criteria analysis of Slope $(P)$, gross subdivision index $\left(I_{l o t}\right)$, and urban drainage density $\left(D_{u r b}\right)$. The consistency threshold is $2 \%$ and validated ( $R C=2 \% \leq 10 \%$ ) according to Saaty, (1980), and Saaty, (2008).

An increase in space occupation of $3 \%$ of the basin is observed on Ganré between 2004 and 2014, against a quasi-stationary occupation on the Kokouro over the same period. However, these two basins seem to have accessibility thresholds in the same order of magnitude. We note that the trend is to increase the settlement of populations on the Ganré but with positions that do not significantly harm aquatic environments. Among the most significant classes, only the Mod class saw a net increase $(3.14 \%)$ to the detriment of the weaker classes (TFa: $-2.11 \%)$ and TFo $(-2.81 \%)$. The slight rise of the Fo class $(+1.48 \%)$ nevertheless expresses that the interest of steep-slope areas has grown in the basin and could continue in the coming decade as classes TFa and Fa are down. From these observations between Ganré and Kokouro, we can hypothesize full growth of the urban installation on the Ganrébasin while on the Kokouro, the urban fabric is

Table 4. Weights and consistency index.

\begin{tabular}{cccccccc}
\hline $\mathrm{Vp}$ & $\mathrm{Cp}$ & $\mathrm{Cp} \%$ & $\mathrm{D}$ & $\mathrm{E}$ & $\lambda$ & $\mathrm{IC}$ & $\mathrm{IA}$ \\
\hline 2.52 & 0.59 & $59 \%$ & 1.799 & 3.032 & & & \\
1.44 & 0.34 & $34 \%$ & 1.030 & 3.020 & & & \\
0.28 & 0.06 & $6 \%$ & 0.196 & 3.003 & & & \\
4.24 & $\mathbf{1 . 0 0}$ & $\mathbf{1 0 0 \%}$ & 3.03 & 9.06 & & & \\
\hline
\end{tabular}



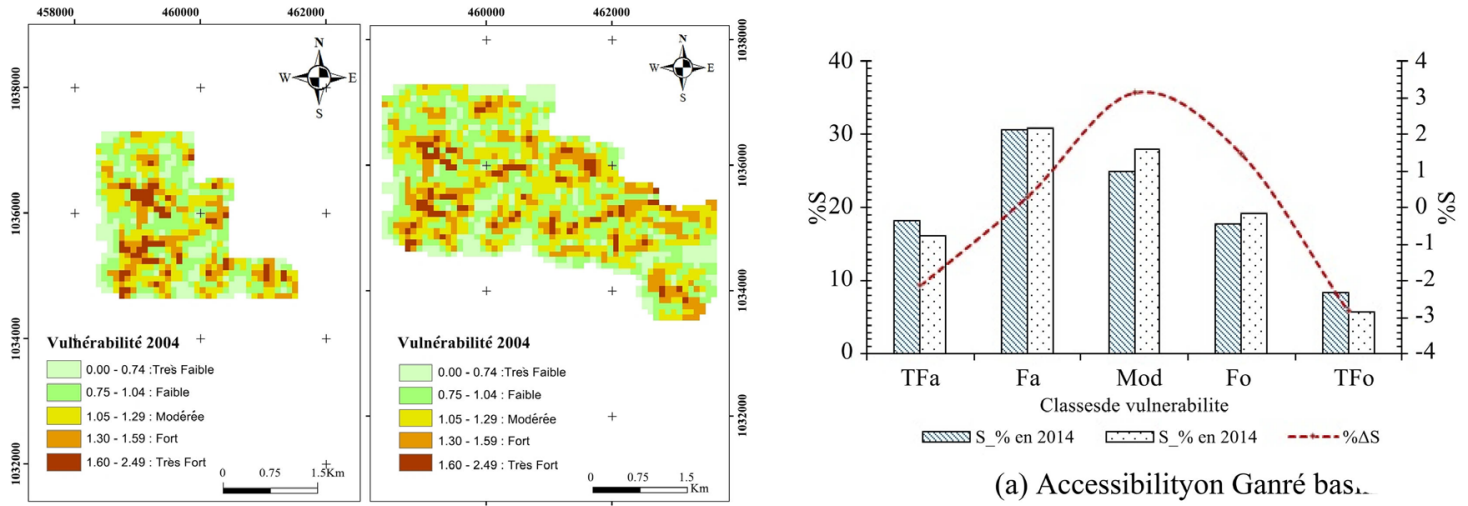

(a) Accessibilityon Ganré bas.
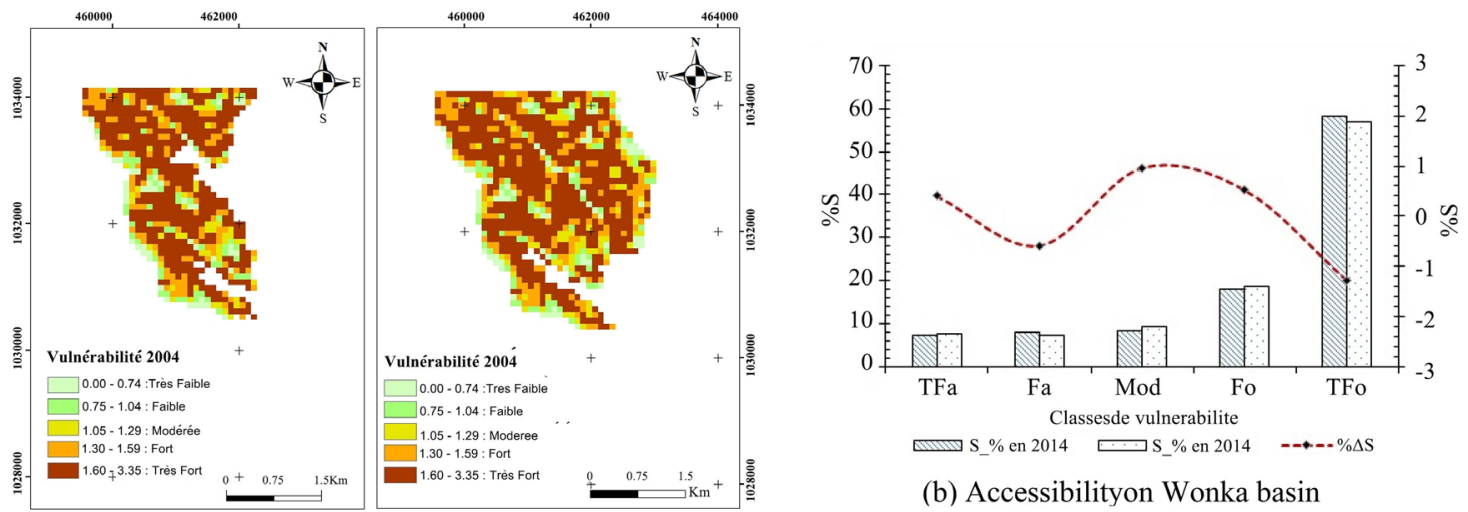

S_\% en $2014 \quad \mathrm{~S}_{-} \%$ en $2014 \quad \cdots \cdots$-...

(b) Accessibilityon Wonka basin


(c) AccessibilityonKokouro basin


(d) Accessibilityon Dama basin

Figure 3. Accessibility of surface water on the Okpara basins at Parakou. 
undergoing restructuring due to the attraction of the supply neighboring basins, or a paradigm shift in the basin. Wonka and Dama are similar in the distribution of accessibility classes. At over $50 \%$, their aquatic networks are highly vulnerable to accessibility. This means that urban facilities occupy a highly compact area around the drainage network. From 2004 to 2014, there was a spatial increase of $2 \%$ ( $4 \%$ in 2004 and $6 \%$ in 014 ) on the Wonka, and only $1 \%$ on the Dama ( $8 \%$ in 2004 and 9\% in 2014). This variation accompanies the amplitude of the transition of accessibility classes which varies between $-0.11 \%$ and $+1.33 \%$ on the Dama against $+0.40 \%$ to $-1.92 \%$ on the Wonka. The administrative and commercial zoning, and industrial of the city of Parakou as a whole, makes the Dama Basin, the basin of reception of the industrial zone with a relative neighborhood of the main market of the city. The Wonka Basin is divided into the commercial activities of the North Zone and the medium-to-high standard housing in the corridor next to the Ganré.

\section{Conclusion}

We observe through this study that the geomorphometric characteristics of watersheds significantly influence the vulnerability of surface water through the accessibility index. The topographic conditions and the human installation rate are two parameters of great importance and which are positioned as control and response factors respectively in relation to the drainage density of the basins. This interrelation highlighted justifies the interest of Saaty's multicriteria analysis method in assessing the vulnerability of surface water from several dependent factors.

\section{Acknowledgements}

The authors demonstrate their gratitude to the embassy of the Netherlands which, thanks to NICHE-BEN-167 for supporting the PhD program in National Institute of water in Benin.

\section{Conflicts of Interest}

The authors declare no conflicts of interest regarding the publication of this paper.

\section{References}

[1] Mae-Wan, H. (2012) C'est l'approvisionnement du monde en eau qui est menacé. ISIS EAU, 8.

[2] Serghini, M. (2004) L'eau, élément conflictuel. New Medit, 3, 60-63.

[3] Barhoumi-Andreani, Y., Gaudremeau, J., Gerbe, B., Khamsing, F. and Rabatel, Y. (2004) Eau, ressources et menaces.

[4] Honegger, A.R. and Bravard, J.-P. (2005) La pénurie d'eau, donnée naturelle ou question sociale. Géocarrefour, 80, 257-259.

[5] Bendraoua, F. and Souiah, S.-A. (2008) Quand les pouvoirs publics produisent de nouvelles marginalités urbaines: Les recasés de Nedjma à Oran (Algérie). Revue 
Autrepart, 45, 173-190. https://doi.org/10.3917/autr.045.0173

[6] Gouamene, D.C., Oura, K.R. and Ouattara, S. (2017) Etalement Urbain et Tensions Foncieres Dans Les Villages Peripheriques De Daloa (Centre-Ouest, Cote d'Ivoire). European Scientific Journal, 13, 217-233. https://doi.org/10.19044/esj.2017.v13n35p217

[7] Chippaux, J.-P., Pernot, C., Jouanneau, D., Clornei, G., Moulin-Esnart, P. and Couret, D. (2007) Évaluation de la potabilité de l'eau dans une zone peuplée du Sahel sénégalais: Niakhar. Environnement, Risques \& Santé, 6, 373-381.

[8] Ferro, Y. (2013) Evaluation de l'impact des rejets urbains de temps de pluie sur le compartiment algal des écosystèmes aquatiques Mise au point d'outils pour la surveillance des milieux récepteurs. Sciences de l'Environnement Industriel et Urbain, Institut national des sciences appliquées de Lyon, Lyon.

[9] Gasperi, J. (2013) Organic contaminants in urban aera and anthropized hydrosystems. Environmental Sciences, Universite Paris XII Val de Marne, Paris.

[10] El Moriht, M., et al. (2008) Impact de l'aménagement hydraulique sur la qualité des eaux et des sédiments de l'estuaire du Loukkos (côte atlantique, Maroc). Bulletin de L'Institut Scientifique, Rabat, Section Science de la Terre, 30, 39-47.

[11] Ohou-Yao, M.J.A., Séka, A.M., Mambo, V., Yapo, O.B., Konan, K.F. and Houénou, P.V. (2014) Contamination des eaux de puits traditionnels par les nitrates sur le bassin versant de la Lobo (Buyo, sud-ouest de la Côte d'Ivoire). Journal of Applied Biosciences, 78, 6654-6665. https://doi.org/10.4314/jab.v78i1.11

[12] Soncy, K., et al. (2015) Évaluation de la qualité bactériologique des eaux de puits et de forage à Lomé, Togo. Journal of Applied Biosciences, 91, 8464-8469. https://doi.org/10.4314/jab.v91i1.6

[13] Aller, L., Bennet, T., Lehr, J., Petty, R. and Hackett, G. (1987) Drastic: A Standardized System for Evaluating Ground Water Pollution Potential Using Hydrogeologic Settings. EPA-6002-87-035, 455.

[14] Amharref, S., Aassine, S., Bernoussi, A. and Haddouchi, B.Y. (2007) Cartographie de la vulnérabilité à la pollution des eaux souterraines: Application à la plaine du Gharb (Maroc). Water Science, 20, 185-199. https://doi.org/10.7202/015812ar

[15] Eba, A.E.L., et al. (2016) Évaluation de la Vulnerabilite A La Pollution D’une Eau De Surface Destinee A L'adduction D'eau Potable D'une Metropole. Cas De La Lagune Aghein A Abidjan, (Sud De La Cote D'ivoire). European Scientific Journal, 12, 306-326. https://doi.org/10.19044/esj.2016.v12n36p306

[16] Hamza, M.H., Added, A., Francès, A., Rodriguez, R., Ajmi, M. and Abdeljaoued, S. (2008) Évaluation de la vulnérabilité à la pollution potentielle de la nappe côtière alluvionnaire de Meltine-Ras Jebel-Raf Raf (Nord-Est tunisien) selon les méthodes paramétriques DRASTIC, SINTACS et SI. Revue des Sciences de P eau, 21, 1-98. https://doi.org/10.7202/017932ar

[17] Sinan, M., Maslouhi, R. and Razack, M. (2003) Utilisation des SIG pour la caractérisation de la vulnérabilité et de la sensibilité à la pollution des nappes d'eau souterraine. Application à la nappe du Haouz de Marrakech. In TS11 Management of Water Resources, Marrakech, Morocco.

[18] Baki, S., Hilali, M., Kacimi, I., Mahboub, A., Kassou, N. and Nouyiti, N. (2016) Etude de la vulnérabilité intrinsèque à la pollution et qualité des eaux de surface dans les zones arides: Cas du bassin versant de l'oued Rhéris (Sud-Est du Maroc). Journal of Materials and Environmental Science, 7, 3961-3972.

[19] INSAE (2014) National Institute of Statistics Applied and the Economy.

[20] Douay, D. and Lardieg, E. (2010) Délimitation des Aires d'Alimentation des Cap- 
tages prioritaires du bassin Adour Garonne méthodologie de cartographie de la vulnérabilité intrinsèque des captages d'eau superficielle. Agence de l'Eau AdourGaronne.

[21] Adamou, R., Alhou, B. and Garba, Z. (2015) Impact de la pollution anthropique du fleuve Niger sur la prolifération de la jacinthe d'eau. Journal of Sciences, 15, 25-38.

[22] Bahroun, S. and Kherici, B.H. (2011) Evaluation de l'indice de pollution organique dans les eaux de surface naturelles: Cas de la région d'El Tarf (Nord-Est Algérien). Larhyss Journal, 9, 171-178.

[23] Bedell, J.-P., et al. (2003) Proposition d'une méthodologie d'évaluation des risques écotoxicologiques liés à la mise en dépôt sur sol ou en gravière de sédiments de dragage. Bulletin des Laboratoires des Ponts Chaussées, 244-245, 131-142.

[24] Dorioz, J.M. (2013) Mechanisms and Control of Agricultural Diffuse Pollution: The Case of Phosphorus and Its General Application. Biotechnology, Agronomy, Society and Environment, 17, 277-291.

[25] Figuet, C. and Frangi, J.-C. (2000) les cours d'eau récepteurs de rejets de stations d'épuration: Le cas de la Mauldre (ile de France) un milieu sous très haute pression. Revue des Sciences de Peau, 13, 119-138. https://doi.org/10.7202/705385ar

[26] Ba, F., Bouchard, C. and Abi-zeid, I. (2011) Analyse multicritère pour la priorisation des interventions en matière d'approvisionnement en eau en milieu rural au Sénégal: Cas de la région de Diourbel. Water Science, 24, 9-22. https://doi.org/10.7202/045824ar

[27] Bascopé, R. (2015) Analyse multicritère pour l'évaluation de la vulnérabilité territoriale aux séismes. L'exemple de Mendoza, Argentine.

[28] Saaty, T.L. (1980) The Analytic Hierarchy Process. https://doi.org/10.21236/ADA214804 